\title{
KRISIS EKONOMI KRISIS POLITIK DUNIA DAN IHSG
}

\author{
Vidyarto Nugroho dan Ishak Ramli \\ FE Universitas Tarumanagara, Jakarta Indonesia, \\ vidyartonugroho@yahoo.co.iddanishakr@fe.untar.ac.id
}

\begin{abstract}
The global economic crisis of 2008-2010 had an impact on the global economic slowdown. Plus the political crisis in the countries of the Middle East region called the Arab Spring had become the center of world attention, because it also lowers economic conditions and corporate America and in other developing countries. By using daily data price of crude oil, the price of gold and exchange rates as well Rp./USD IDX Composite Index from the year 2010 - 2012, tested the impact of crude oil prices, global gold prices on the Stock Exchange Composite Index. The result was at the time of global economic and political crisis in oil prices and the world gold price positively affects JCI opposed to when normal conditions. When the economic crisis plus the political crisis that led to the oil price increases, the share price (CSPI) on the Stock Exchange also increased. Funds drawn investors from investing in the United States and other developing countries is invested in Indonesia so that stock prices rise along with oil prices and gold prices. While the exchange rate negatively affects Rp./USD JCI Stock Exchange, as a stronger rupiah lead JCI Stock Exchange also increased
\end{abstract}

Keywords: Stock exchange, economic crisis, IHSG, developing countries, IDX

\begin{abstract}
Abstrak: Krisis ekonomi global tahun 2008-2010 membawa dampak pada menurunnya perekonomian global. Ditambah lagi krisis politik di negara-negara kawasan Timur tengah yang disebut dengan Arab Spring sempat menjadi pusat perhatian dunia, karena juga menurunkan kondisi perekonomian dan perusahaan di Amerika dan di Negara berkembang lainnya. Dengan menggunakan data harian harga minyak mentah, harga emas dunia, dan kurs Rp./USD serta IHSG di BEI dari tahun 2010 - 2012, diuji dampaknya harga minyak mentah, harga emas dunia pada IHSG di BEI. Hasilnya ternyata pada saat krisis ekonomi dan politik global harga minyak dan harga emas dunia positif mempengaruhi IHSG bertentangan dengan bila kondisi normal. Saat krisis ekonomi ditambah krisis politik yang menyebabkan harga minyak meningkat maka harga saham (IHSG) di BEI juga meningkat. Dana investor yang ditarik dari investasi di Amerika dan Negara berkembang lainnya diinvestasikan di Indonesia sehingga harga saham meningkat seiring dengan peningkatan harga minyak dan harga emas. Sementara kurs Rp./USD negatif mempengaruhi IHSG BEI, karena menguatnya rupiah menyebabkan IHSG BEI juga meningkat.
\end{abstract}

\section{PENDAHULUAN}

Pada krisis Global tahun 2008 dunia mengalami krisis ekonomi yang bermula dari negara adidaya Amerika Serikat berimbas ke perekonomian seluruh negara di dunia. Belum juga hilang dampak krisis ekonomi global pada tahun 2008, pada awal tahun 2011 terjadi krisis politik di negara-negara kawasan Timur tengah yang disebut dengan Arab Spring dan 
sempat menjadi pusat perhatian dunia. Terjadi gejolak politik yang sangat menegangkan dan efeknya sangat terasa secara luas (global).

Di saat yang bersamaan, harga minyak mentah dunia mengalami kenaikkan dan dapat memberikan dampak luas kepada perekonomian di dunia. adanya ketegangan di negara Suriah yang berdampak pada distribusi minyak di kawasan Timur Tengah dan konflik bersenjata antara kaum oposisi dan tentara pemerintah juga ikut mendorong harga minyak naik. Selain itu, harga emas dunia juga mengalami kenaikkan yang cukup signifikan. Indonesia pun tidak luput dari dampak tersebut selaku salah satu negara dalam perekonomian global. Namun, ketika terjadi kenaikkan harga minyak mentah dan emas dunia, harga saham IHSG justru tidak menunjukkan pergerakan yang signifikan. Berikut adalah data historical harga minyak mentah dunia, harga emas dunia dan IHSG:

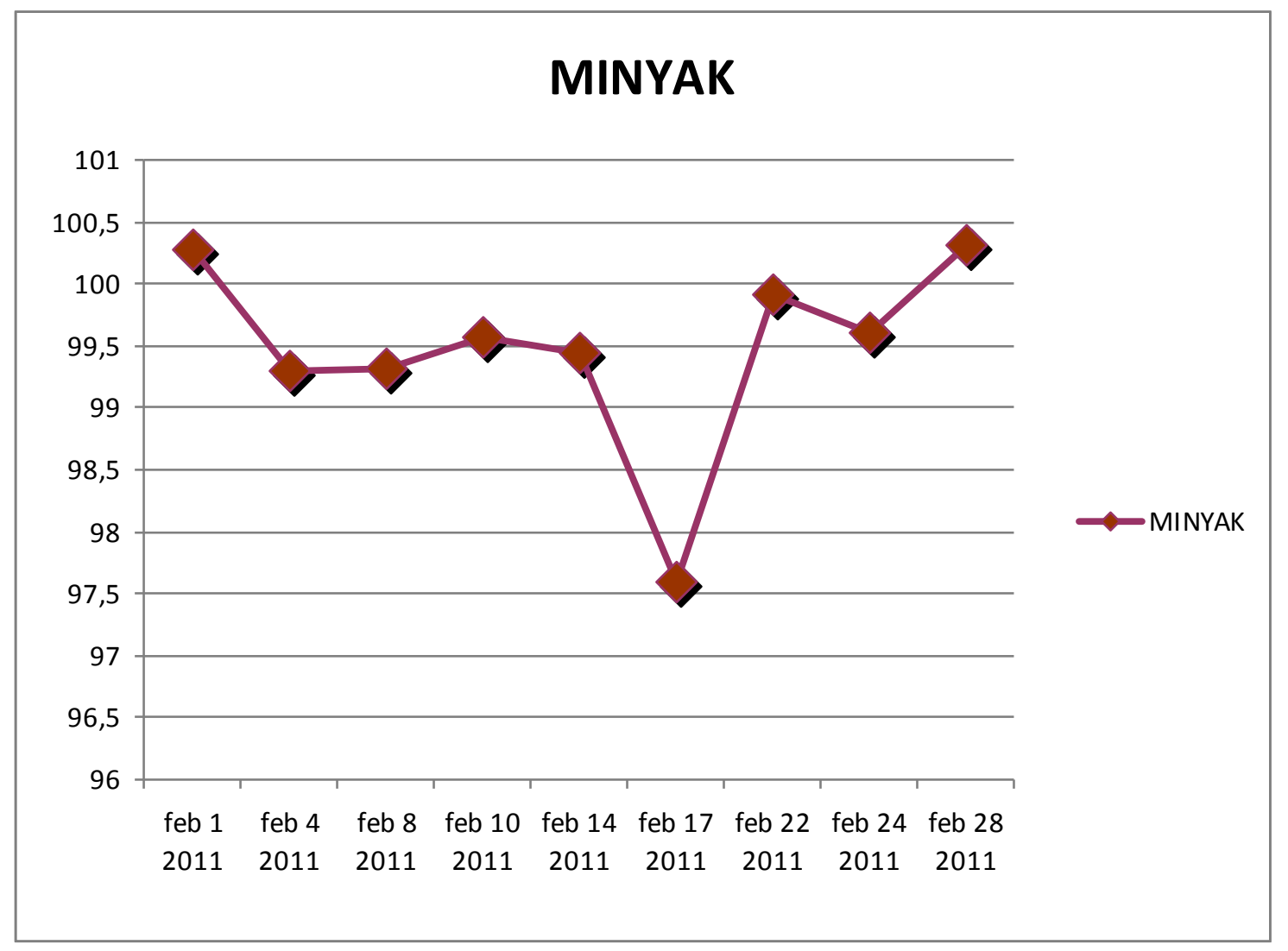

Gambar 1. Harga Minyak Mentah Dunia

Sumber : wsj.com ( Wall Street Journal)

Harga minyak mentah dunia mengalami kenaikan harga pada periode 8 Febuari - 10 Febuari 2011. Pada tanggal 8 Febuari, harga minyak berada di kisaran $\$ 99,31$ per barrel, dan naik ke level $\$ 99,56$ per barrel pada 10 Febuari, harga minyak sempat turun tipis ke level $\$ 99,44$ per barrel pada 14 Febuari, namun, harga minyak turun drastis ke level $\$ 97,60$ pada tanggal 17 Febuari. Pada 28 Febuari harga minyak di tutup di level \$100,31. 


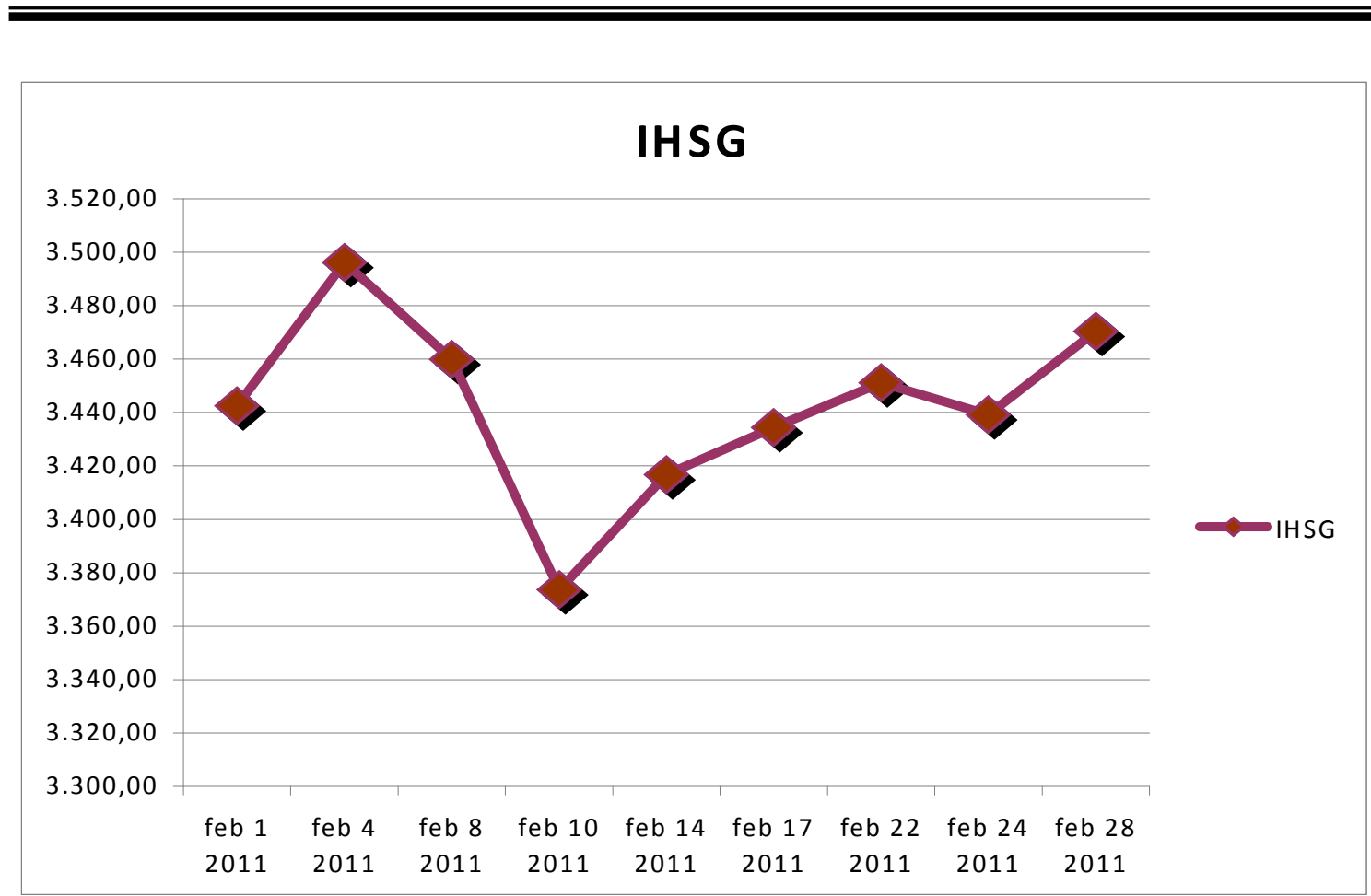

Gambar 2. Indeks Harga Saham Gabungan

Sumber : yahoo.finance.com (Yahoo Finance)

Pada Gambar 1.2, dapat dilihat pergerakan harga saham IHSG pada periode 8 Febuari - 10 Febuari 2011 mengalami penurunan yang signifikan. Pada 8 Febuari IHSG di tutup di level 3,459.93, pada 10 Febuari IHSG di tutup turun drastis ke level 3,373.64. Di periode 24 Febuari, IHSG kembali naik dan di tutup di level 3,439.13, begitu pula di 28 Febuari 2011, IHSG kembali naik dan di tutup di level 3,470.35.

Pada Gambar 3, dapat dilihat bahwa harga emas dari periode 8-10 Febuari mengalami kenaikkan. Pada 8 Febuari harga emas ditutup di level 1363,15. Pada 10 Febuari harga emas mengalami kenaikkan dan di tutup di level 1364,45. Pada 24 Febuari harga emas kembali naik ke level 1402,05. Puncaknya terjadi pada 28 Febuari dimana harga emas naik hingga ke level 1411,25. Dari ketiga Gambar diatas, terlihat bahwa kenaikkan harga yang terjadi pada minyak mentah dunia dan Emas dunia di periode 8-10 Febuari 2011 tidak diikuti naiknya harga saham IHSG, justru IHSG mengalami penurunan pada periode yang sama. Fakta diatas tidak sesuai dengan hasil penelitian yang telah di lakukan oleh papapetrou (2001), Basher \& Perry sadorsky (2004) dan Chang, Youngho \& Wong, Joon Fong, (2003)." yang menghasilkan bahwa harga minyak mentah dunia mempengaruhi harga saham, terutama di negara emerging market (negara berkembang). Selain itu, Fama (1990) menemukan bukti bahwa harga minyak mentah dunia mempengaruhi IHSG. Le, Thai-Ha \& Chang, Youngho (2011) menemukan bahwa reaksi pasar saham atas guncangan harga minyak mentah dunia bervariasi. Reaksi positif ditunjukkan oleh pasar saham di Jepang, sedangkan di Malaysia reaksinya negatif.

Hasil lain juga di kemukakan oleh Cong, Rong-Gang \& Wei, Yi-Ming \& Jiao, JianLin \& Fan, Ying (2008) yang menemukan bahwa kenaikkan harga minyak mentah dunia ikut menaikkan harga saham di China. Hasil berbeda di kemukakan oleh Chittedi (2011) yang menemukan bahwa harga minyak mentah dunia tidak mempengaruhi harga saham di India. Selain itu, menurut penelitian yang dilakukan Bambang Darmadi, Widiyarsih, dan 
Anti (2009) menemukan bahwa kenaikkan harga minyak mentah dunia berpengaruh positif dan tidak signifikan terhadap nilai IHSG.

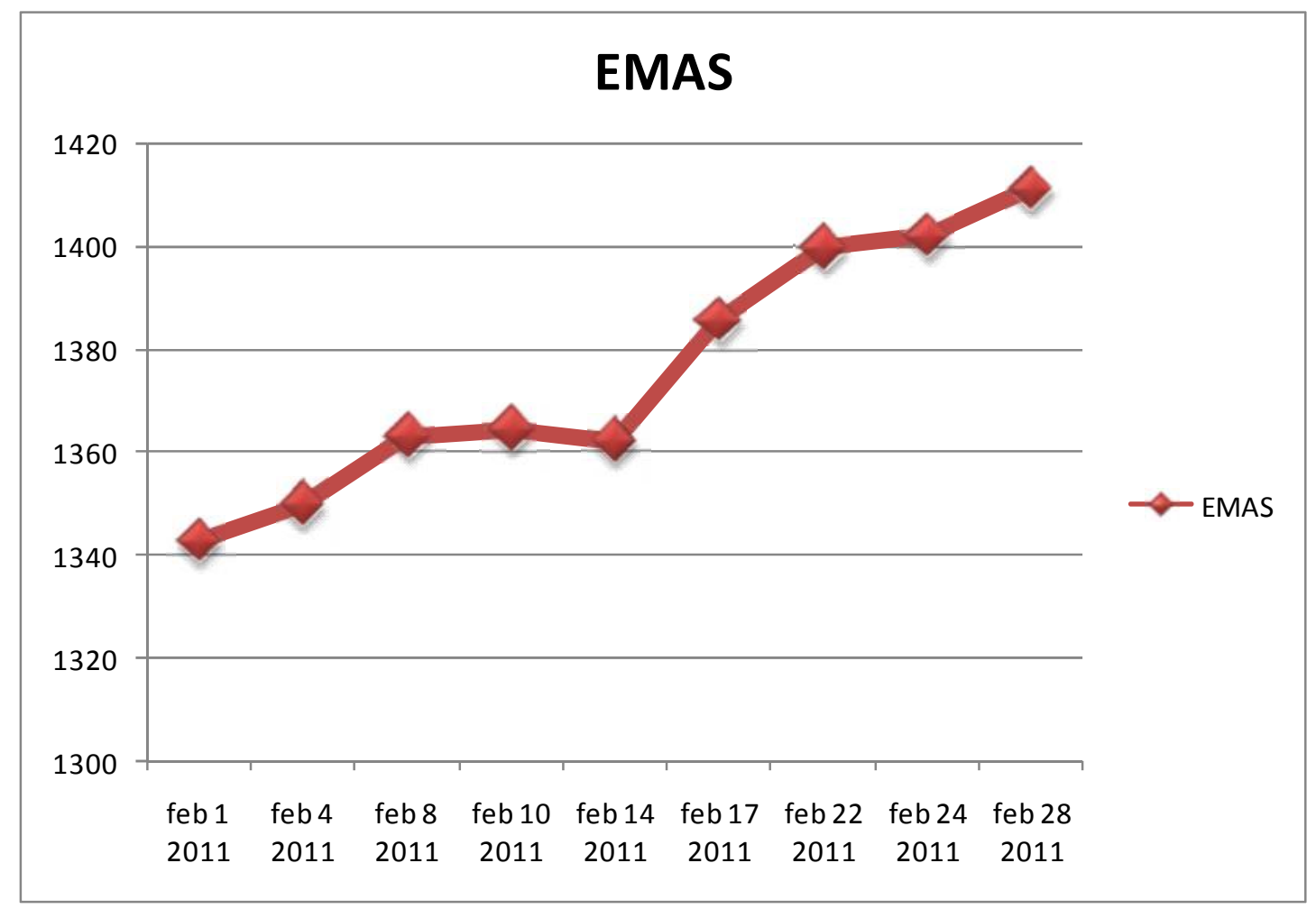

Gambar 3. Harga Emas Dunia

Sumber: forexpros.com ( Forex Pross )

Basher dan Sadorsky (2006) menemukan adanya hubungan antara harga minyak mentah dunia dengan harga saham negara-negara emerging markets di wilayah Asia Tenggara. Fakta diatas juga tidak sesuai dengan penelitian yang dilakukan oleh Sunariyah (2006), yang menyatakan harga emas cendrung mempengaruhi IHSG karena harganya stabil dan bebas resiko. Hasil serupa juga di kemukakan oleh Indra Wijaya dkk (2008) yang menyatakan bahwa harga emas dunia mempunyai pengaruh terhadap harga saham, karena emas merupakan pelindung nilai saham dalam jangka panjang.

Selain kedua faktor diatas, hasil lain dikemukakan oleh Widiyarsih, dan Anti (2009), yang menemukan bahwa nilai tukar (kurs) mempunyai pengaruh yang negatif dan signifikan terhadap IHSG. Hasil serupa juga ditemukan oleh Tim Peneliti PPS (2001) bahwa kurs mempunyai pengaruh yang negatif dan signifikan terhadap IHSG. Sunariyah (2006) menemukan bahwa nilai kurs yang terdepresiasi akan menurunkan IHSG.

Aydemir dan Demirhan (2008) juga menemukan bahwa adanya pengaruh negatif dari nilai tukar mata uang asing terhadap seluruh indeks pada pasar saham di negara Turki. Hasil ini berbeda dengan yang di kemukakan oleh Adam dan Tweneboah (2008) yang menemukan bahwa pengaruh nilai mata uang asing terhadap indeks bursa saham di negara Ghana sangat lemah. Mukherjee dan Naka (1995) menemukan bahwa terdapat hubungan yang positif antara harga saham dengan nilai tukar di Indonesia, Malaysia dan Philiphina. Sedangkan menurut Maysami dan Koh (2000) menyatakan bahwa tidak ada hubungan 
antara harga saham dengan nilai tukar di Singapura dan Thailand. Abdalla dan Murinde (1997) menemukan bahwa nilai tukar mempengaruhi harga saham di India, Pakistan dan Korea.

Selain faktor-faktor tadi, ada beberapa faktor lagi yang berpengaruh atau memiliki hubungan dengan IHSG dan harga saham. Hasil penelitian yang dilakukan oleh Tim Peneliti PPS (2001) menemukan bahwa inflasi dan tingkat suku bunga mempunyai pengaruh yang negatif dan signifikan terhadap IHSG. Sedangkan Daryono (2003) menemukan bahwa suku bunga mempunyai hubungan negatif dengan IHSG, sedangkan inflasi dan jumlah uang yang beredar memberikan pengaruh positif bagi IHSG.

Mukherjee dan Naka (1995), Adjasi dan Biekpu (2006) menemukan bahwa terdapat hubungan yang negatif antara harga saham dengan tingkat suku bunga. Namun, penelitian yang dilakukan oleh Gjerde dan Saettem (1999), menemukan bahwa tingkat suku bunga mempengaruhi saham di Norwegia.

Osei (2006), Rahman et al (2009) dan Chen et al (2005) menemukan bahwa terdapat hubungan yang positif antara harga saham dengan jumlah uang yang beredar (money supply). Fama (1981) dan Spyrou (2001) menemukan adanya hubungan negatif antara inflasi dan harga saham. Hasil berlawanan justru ditemukan oleh Firth (1979) dan Gultekin (1983) yang menyatakan bahwa terdapat hubungan yang negatif antara inflasi dengan harga saham. Paulus dkk (2003) juga menemukan inflasi tidak berpengaruh signifikan terhadap harga saham.

Selain itu, Menurut Situngkir, Hokky (2012) pasar saham di Indonesia dipengaruhi juga oleh faktor ekonomi, sosial, dan politik. Sunariyah (2006) menemukan bahwa indeks bursa dunia akan meningkatkan IHSG.

Berdasarkan literatur terdahulu, perlu diteliti bagaimana krisis ekonomi dan politik global mempengaruhi IHSG terkait harga minyak mentah dunia, harga emas dunia dan kurs IDR/US\$.

Permasalahan dalam peneliian ini adalah: (1) Apakah harga minyak mentah dunia mempengaruhi IHSG di BEI saat kriris ekonomi dan politik Global; (2) Apakah harga emas dunia mempengaruhi IHSG di BEI saat kriris ekonomi dan politik Global; (3) Apakah nilai tukar mata uang IDR/US\$ mempengaruhi IHSG di BEI saat kriris ekonomi dan politik Global; (4) Apakah harga minyak mentah dunia, harga emas dunia, dan nilai tukar mata uang IDR/US\$ mempengaruhi IHSG di BEI saat kriris ekonomi dan politik Global.

\section{KAJIAN TEORI}

Indeks Harga Saham Gabungan (IHSG). Indeks harga saham gabungan (IHSG) merupakan indeks semua saham yang tercatat sebagai komponen perhitungan indeks (Darmadji dan Fakhrudin, 2001:96). Didesain untuk memberikan informasi mengenai pergerakan pasar saham sebagai alat pertimbangan bagi para investor yang ingin berinvestasi saham) (Jones , 2002:90 ) dan dipengaruhi oleh faktor besarnya kapitalisasi pasar suatu saham (Menurut Thian Hin, 2008:4).

Pengaruh Harga Minyak Mentah Dunia terhadap Indeks Harga Saham Gabungan. Pahl dan Ritcher (2009:8-9), menjelaskan bahwa harga minyak mentah dunia adalah hasil dari transaksi-transaksi yang terjadi secara terus-menerus di seluruh belahan dunia, pada setiap tingkatan distribusi dari penghasil minyak mentah sampai ke konsumen individu. 
WTI (West Texas Intermediate) yang diperdagangkan di NYMEX (New York Merchantile Exchange) lebih banyak dinotasikan sebagai barometer harga minyak mentah dunia dibandingkan Brent Crude yang diperdagangkan di IPE (London's International Petroleum Exchange). Harga minyak mentah dunia menjadi patokan dalam Futures market yang diperdagangkan untuk kemudian diserahkan pada waktu tertentu. Nilai yang sering menjadi menjadi patokan dalam pasar minyak mentah dunia adalah WTI (West Texas Intermediate). Harga minyak berasal dari transaksi-transaksi minyak yang terjadi secara terus-menerus untuk kemudian dijadikan patokan dalam penentuan harga minyak mentah dunia. Dan nilai yang sering menjadi patokan dalam pasar minyak mentah dunia adalah WTI (West Texas Intermediate) yang diperdagangkan di NYMEX (New York Merchantile Exchange).

Menurut penelitian yang dilakukan oleh Huang, Masulis dan Stoll (1996) yang dilakukan pada NYMEX (New York Merchantile Exchange) dengan periode 1983-1990, dijelaskan bahwa minyak bersama-sama dengan modal (capital), tenaga kerja (labor) dan persediaan bahan baku mentah (inventory) merupakan komponen penting dari sebuah proses produksi sehingga perubahan harganya mempengaruhi kinerja keuangan perusahaan. Kenaikan harga minyak mentah dunia yang hingga saat ini masih belum ada alternatif penggantinya sehingga mengakibatkan naiknya biaya produksi. Naiknya biaya produksi mengakibatkan berkurangnya cashflow sehingga berdampak pada penurunan harga saham. Dan saat harga saham menurun, maka secara otomatis saham perusahaan tersebut akan sepi peminat di bursa efek. Para investor enggan untuk berinvestasi dengan membeli saham perusahaan yang harganya tidak stabil dan cendrung menurun.

Le, Thai-Ha \& Chang, Youngho (2011) yang melakukan penelitian di Jepang dengan menggunakan data bulanan selama Januari 1986- Febuari 2011 yang terdiri dari 302 observasi. Data yang digunakan merupakan data time series yang telah di ubah kedalam bentuk logaritma, data harga minyak dunia yang digunakan adalah data dari WTI (World Texas Intermediate).

Sedangkan data harga saham yang digunakan adalah data dari bursa efek di Jepang (Japan Stock Exchange). Dari hasil penelitian tersebut, ditemukan bahwa return yang dihasilkan oleh minyak jauh lebih baik daripada return yang dihasilkan oleh pasar saham. Sehingga berinvestasi di sektor minyak di negara Jepang lebih menjanjikan keuntungan ketimbang berinvestasi di sektor saham.

Padahal faktanya Jepang merupakan negara importir minyak terbesar ketiga di dunia setelah Amerika Serikat dan China.Untuk para investor yang risk averter, mereka biasanya memiliki kecendrungan memberikan porsi yang kecil berinvestasi di sektor saham karena tidak mau mengambil resiko. (Whinston and Green 1995).

Pengaruh Harga Emas Dunia terhadap Indeks Harga Saham Gabungan. Emas adalah logam mulia yang paling popular dan digemari karena nilainya tak lekang oleh waktu (Aizid, 2011). Selain itu, harga emas juga selalu stabil setiap waktu dan bersifat likuid (mudah diuangkan). Keunikan lain dari emas ialah mampu menaklukan inflasi karena nilainya stabil. Bila inflasi tinggi, harga emas akan naik lebih tinggi daripada inflasi. Semakin tinggi inflasi, semakin tinggi kenaikkan harga emas. Bila inflasi mencapai $10 \%$, maka harga emas akan naik sekurangnya 13\%. Bila inflasi 20\%, maka harga emas akan naik sekitar 30\%. Sehingga emas banyak dijadikan alat save heaven oleh para investor untuk menyelamatkan kekayaanya.

Harga emas dunia ditetapkan di pasar emas dunia dalam dollar AS per troy ounce (Mohamad Ihsan Palaloi dkk, 2006 ). Satu troy ounce setara dengan 31,103 gram emas 
murni. Harga emas harga logam mulia yang paling stabil dibanding dengan harga logam mulia lainya di pasaran (Sari et al , 2010 ) Emas juga produktif sebagai sarana investasi, banyak investor membeli batangan-batangan emas untuk kemudian disimpan di gudanggudang bawah tanah (basement). Itulah sebabnya John White (1997; 295-296 ) mengatakan bahwa emas adalah jenis investasi yang aneh, emas digali dari tanah untuk selanjutnya disimpan di bawah tanah.

Menurut Indra, Joyce dan Keni (2008), emas memiliki kinerja out performed jika dibandingkan dengan alat investasi lainya pada saat melakukan penyesuaian terhadap gejolak inflasi, hal tersebut sangat masuk akal mengingat emas merupakan suatu alat proteksi dalam jangka panjang yang memiliki tingkat resiko yang paling kecil jika dibandingkan dengan medium investasi lainya. Sehingga harga emas memiliki pengaruh yang signifikan terhadap harga saham.

Penelitian lain yang mendukung dilakukan oleh Sunariyah (2006) yang menemukan bahwa harga emas cendrung mempengaruhi Indeks Harga Saham Gabungan karena harganya stabil dan bebas resiko. Le, Thai-Ha \& Chang, Youngho (2011) yang melakukan penelitian di Jepang menggunakan data harga emas dan data saham bulanan dari Januari 1986 - Febuari 2011 menggunakan data time series. Dalam penelitian tersebut, ditemukan bahwa return yang dihasilkan oleh emas jauh lebih besar daripada return yang dihasilkan oleh saham di Jepang. Ini berarti berinvestasi di sektor emas jauh lebih menjanjikan ketimbang berinvestasi saham. Selain itu, hasil tersebut didukung oleh fakta yang dikemukakan oleh IMF ( International Financial Statistic ) yang menyebutkan bahwa Jepang merupakan salah satu negara dengan cadangan emas terbesar di dunia.

Pengaruh Nilai Tukar Mata Uang Asing Terhadap Indeks Harga Saham Gabungan. Ketika Dollar Amerika mengalami kenaikan, para investor akan berbondong-bondong menjual saham dan ditempatkan di bank dalam bentuk Dollar, dengan begitu harga saham akan menurun. Namun, ketika dollar amerika mengalami penurunan maka para investor cendrung akan membeli atau mempertahankan saham mereka. Dari sini dapat terlihat bahwa valuta asing memiliki double effect terhadap harga saham. Sedangkan penelitian yang dilakukan oleh Adam dan Tweneboah (2008) pada pasar saham di Ghana dengan menggunakan periode 1991-2007, dijelaskan bahwa depresiasi dari nilai tukar mata uang asing akan berdampak pada naiknya harga barang yang diimpor. Hal ini disebabkan oleh turunnya nilai mata uang domestik, sehingga dibutuhkan lebih banyak mata uang domestik yang dikorbankan untuk memperoleh barang impor yang dihargai oleh mata uang asing. Dengan demikian akan mengurangi arus kas pada perusahaan yang kegiatanya mengimpor, dan otomatis akan membuat harga saham perusahaan tersebut menurun.

Ajayi (2006) melakukan penelitian di Thailand, Hongkong, Singapura, Korea Selatan dan Taiwan dari 6 Januari 1997 - 31 Desember 1999 menemukan bahwa nilai tukar mata uang asing ( Dollar Amerika ) memberikan pengaruh yang negatif dan signifikan terhadap return saham di Korea Selatan, Singapura dan Thailand. Jadi, berinvestasi saham di Korea Selatan, Singapura dan Thailand cukup beresiko karena fluktuasi harga saham di negaranegara tersebut bergantung pada pergerakan kurs valuta asing. Hanya di Hongkong dimana harga sahamnya tidak terpengaruh oleh pergerakan valuta asing.

Hipotesis.Dari kerangka teori yang telah dibuat, diperoleh beberapa hipotesis sebagai berikut:

$\mathrm{H}_{1}$ : Harga minyak mentah dunia negatif mempengaruhi IHSG di BEI saat krisis ekonomi dan politik global. 
$\mathrm{H}_{2}$ : Harga emas dunia mempengaruhi IHSG di BEI saat krisis ekonomi dan politik global..

$\mathrm{H}_{3}$ : Nilai tukar IDR/US\$ mempengaruhi IHSG di BEI saat krisis ekonomi dan politik global..

$\mathrm{H}_{4}$ :Harga minyak mentah dunia, harga emas dunia dan nilai tukar IDR/US\$ mempengaruhi IHSG saat krisis ekonomi dan politik global.

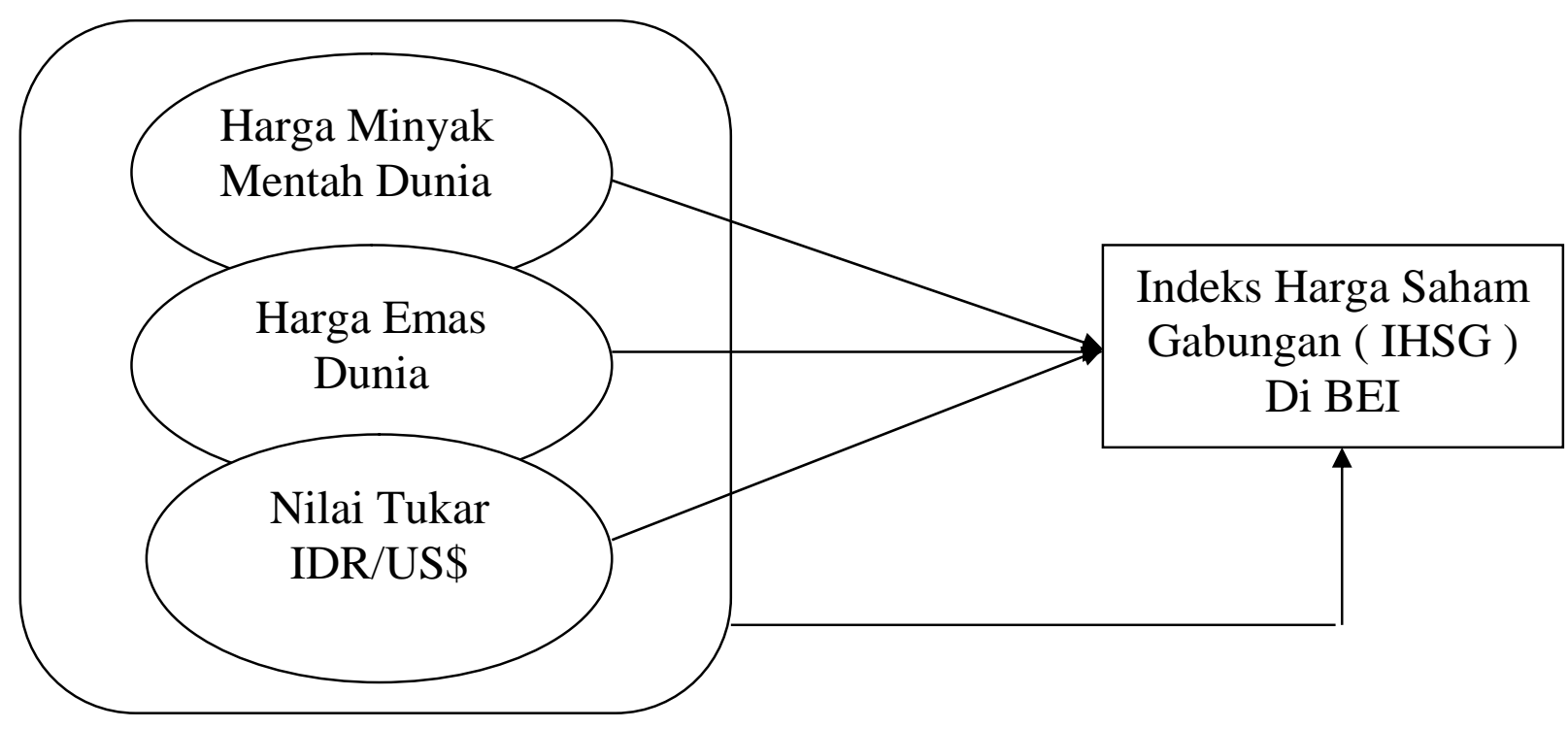

Gambar 3. Kerangka Pemikiran

\section{METODE}

Populasi dan Metode Pemilihan Sampel. Populasi harga minyak mentah dunia yang diperdagangkan, harga emas dunia, nilai tukar mata uang asing terhadap Rupiah, dan data indeks harga saham gabungan ( IHSG ) di BEI saat krisis ekonomi dan politik global.

Pemilihan sampel tak acak bertujuan. Sampel yang digunakan dalam penelitian ini adalah harga minyak mentah dunia jenis WTI, harga emas dunia, nilai tukar mata uang IDR/US\$, dan IHSG di BEI dengan periode harian yang dikumpulkan dari Januari 2010 - Juni 2012.

Metode Pengumpulan Data. Data harga minyak mentah dunia, harga emas dunia, nilai tukar IDR/US\$ dan IHSG diperoleh dari Yahoo Finance, World Street Journal dan Forex Pross selama periode Januari 2010 - Juni 2012. Data yang dibutuhkan dalam penelitian ini diperoleh dengan teknik sebagai berikut:

1. Pengumpulan data dilakukan dengan membuat salinan dari data sekunder. Data masingmasing variabel diperoleh dari: (a) Harga minyak mentah dunia yang merupakan data harian yang dikumpulkan pada penutupan perdagangan setiap hari Senin-Jum'at diperoleh dari (www.wsj.com); (b) Harga emas dunia yang merupakan data harian yang dikumpulkan pada penutupan perdagangan setiap hari Senin-Jum'at diperoleh dari (www.forexpross.com ); (c) Nilai tukar mata uang IDR/US\$ yang merupakan data harian yang dikumpulkan pada penutupan perdagangan setiap hari Senin-Jum'at diperoleh dari (www.forexpross.com);(d) Indeks Harga Saham Gabungan (IHSG) di BEI yang 
merupakan data harian yang dikumpulkan pada penutupan perdagangan setiap hari SeninJum'at diperoleh dari ( $\underline{w w w . y a h o o f i n a n c e . c o m ~})$.

Teknik Analisis Data. Analisis yang digunakan dalam penelitian ini adalah analisis regresi berganda. Uji asumsi klasik diawali dengan uji stationaritas bila data belum stationer, dilakukan differencing agar data stationer. Selanjutnya dilakukan uji multikolinearitas, autokorelasi, heterokedastisitas dan normalitas. Data variabel akan diolah menggunakan komputer dengan dibantu oleh software Eviews 6.0.

\section{HASIL DAN PEMBAHASAN}

Hasil Analisis Data. Analisis yang dilakukan guna mencapai tujuan penelitian digunakan model regresi dengan menguji data meliputi uji stasionaritas data, multikolinearitas, autokorelasi, heterokedastisitas dan normalitas. Dengan menggunakan bantuan program komputer Eviews 6.0, penelitian ini menggunakan tiga variabel bebas (independent variabel) yaitu, Harga Minyak Dunia, Harga Emas Dunia, Nilai Tukar IDR/US\$. Sementara variabel terikat (dependen) yang digunakan adalah Indeks Harga Saham Gabungan (IHSG).

\section{Analisis Regresi Berganda}

Dependent Variable: IHSG

Method: Least Squares

Included observations: 613

\begin{tabular}{lllll}
\hline \hline Variable & Coefficient & Std. Error & t-Statistic & Prob. \\
\hline \hline D(MINYAK) & 12.40949 & 0.999305 & 12.41812 & 0.0000 \\
D(EMAS) & 1.462314 & 0.049657 & 29.44830 & 0.0000 \\
D(KURS) & -0.130968 & 0.037033 & -3.536553 & 0.0004 \\
C & 1457.029 & 368.2536 & 3.956591 & 0.0001 \\
\hline \hline & $=0.819133$ & Mean dependent var & 3516.574 \\
R-squared & 0.818242 & S.D. dependent var & 476.8445 \\
Adjusted R-squared & 0.03 .2934 & Akaike info criterion & 13.47368 \\
S.E. of regression & 203.250251 \\
Sum squared resid & 25168882 & Schwarz criterion & 13.50251 \\
Log likelihood & -4125.683 & Hannan-Quinn criter. & 13.48489 \\
F-statistic & 919.3728 & Durbin-Watson stat & 0.067063 \\
Prob(F-statistic) & 0.000000 & & \\
\hline \hline
\end{tabular}

Model penelitian ini yaitu:

$\log Y_{t^{\prime}}^{\prime}=1457,029+12,409 \log$ minyak t-1 + 1,46 log emas t-1 - 0,131 log idr/us $\$ t_{-1}+e$

Keterangan : $\mathrm{Y}_{\mathrm{t}}{ }^{\prime}=\mathrm{IHSG} ; \mathrm{X}_{1}=$ Harga minyak mentah dunia; $\mathrm{X}_{2}=$ Harga emas dunia; $\mathrm{X}_{3}=$ Nilai tukar IDR/US\$; e = Tingkat Error

Pengujian hipotesis. Uji Hipotesis 1, 2 dan 3 (uji parsial). Uji hipotesis 1, 2 dan 3 (uji parsial) dilakukan dengan uji t (Student Test) dengan menguji koefisien regresi secara 
parsial pengaruh signifikan variabel independen terhadap variabel dependen, variabel independen lain dianggap konstan.

Uji hipotesis 1: harga minyak mentah dunia mempengaruhi IHSG di BEI

Harga minyak mentah dunia positif signifikan mempengaruhi IHSG di BEI variabel independen lain dianggap konstan.

Uji hipotesis 2: harga emas dunia mempengaruhi IHSG di BEI

Harga emas dunia positif signifikan mempengaruhi IHSG di BEI variabel independen lain dianggap konstan.

Uji hipotesis 3: nilai tukar IDR/US\$ mempengaruhi IHSG di BEI

Nilai tukar IDR/US\$ negative signifikan mempengaruhi IHSG di BEI variabel independen lain dianggap konstan.

Uji Hipotesis 4 (Uji ANOVA/ Simultan). Uji hipotesis 4 dilakukan dengan uji F (Fisher Test) dengan menguji koefisien regresi secara bersama-sama, yaitu untuk menguji apakah model pengaruh harga minyak mentah dunia, harga emas dunia dan nilai tukar IDR/US\$ signifikan secara bersama-sama terhadap IHSG di BEI. Model pengaruh cocok menduga IHSG dengan harga minyak mentah dunia, harga emas dunia, dan nilai tukar IDR/US\$ karena $\alpha \leq 5 \%$

Koefisien Determinasi $\mathbf{R}^{\mathbf{2} \cdot}$ Nilai $\mathbf{R}^{2}$ atau koefisien determinasi adalah sebesar 0,818 atau $81,8 \%$, sisanya sebesar 0,182 atau $18,2 \%$ IHSG di BEI dipengaruhi oleh variabel lain seperti inflasi, suku bunga, money supply, indeks bursa dunia dan faktor sosial, ekonomi dan politik.

Pembahasan. Krisis politik yang terjadi pada awal tahun 2011 di negara-negara kawasan Timur Tengah yang disebut dengan Arab Spring dan sempat menjadi pusat perhatian dunia. Terjadi gejolak politik yang sangat menegangkan dan efeknya sangat terasa secara luas (global). Di saat yang bersamaan, harga minyak mentah dunia mengalami kenaikkan dan dapat memberikan dampak luas kepada perekonomian di dunia. adanya ketegangan di Suriah yang berdampak pada distribusi minyak di kawasan Timur Tengah dan konflik bersenjata antara kaum oposisi dan tentara pemerintah juga ikut mendorong harga minyak naik.

Selain itu, harga emas dunia juga mengalami kenaikkan yang cukup signifikan. Sebagai salah satu negara dalam perekonomian global, Indonesia pun tidak luput dari dampak tersebut.. Penelitian ini membuktikan pengaruh harga minyak mentah dunia terhadap IHSG di BEI tidak konsisten dengan penelitian yang dilakukan oleh Basher dan Perry Sadorsky (2004). Pada berbagai pasar saham negara-negara berkembang (emerging markets) selama periode 1992-2004 menemukan bahwa kenaikkan harga minyak memberikan pengaruh yang negatif terhadap kinerja pasar saham. Ini dikarenakan jauh lebih banyaknya jumlah perusahaan yang mengkonsumsi minyak dibandingkan yang memproduksi minyak mengakibatkan kenaikkan harga minyak mentah dunia lebih berdampak negatif terhadap pasar saham. Hal ini membuktikan bahwa pada saat krisis ekonomi dan politik global terjadi pemutar balikan kejadian. Saat krisis ekonomi dan politik global peningkatan harga minyak mentah dunia justru mendorong IHSG BEI. Indonesia sebagai salah satu Negara emerging market justru menikmati dampak peningkatan IHSG karena kenaikan harga minyak mentah dunia. Krisis tersebut menyebabkan harga minyak mentah dunia dan IHSG meningkat menunjukkan para 
investor lebih suka menginvestasikan dananya pada Negara emerging market mengingat harga saham pasar modal Negara berkembang mengalami penurunan..

Penelitian yang dilakukan Huang, Masulis dan Stoll (1996) menemukan bahwa pada NYMEX ( New York Merchantile Exchange) periode 1983-1990 peningkatan harga minyak mentah dunia meningkatkan harga saham. Minyak bersama-sama dengan modal ( capital ), tenaga kerja ( labor ) dan persediaan bahan baku mentah (inventory) merupakan komponen penting dari sebuah proses produksi sehingga perubahan harganya mempengaruhi kinerja keuangan perusahaan. Mengingat bahan bakar minyak masih belum mempunyai alternative pengganti saat itu, maka, kenaikan harga minyak mentah dunia mengakibatkan naiknya biaya produksi. Naiknya biaya produksi mengakibatkan berkurangnya cashflow sehingga berdampak pada penurunan harga saham. Dan saat harga saham menurun, maka secara otomatis saham perusahaan tersebut akan sepi peminat di bursa efek. Para investor enggan untuk berinvestasi membeli saham perusahaan yang harganya tidak stabil dan cendrung menurun. Sedangkan Narayan dkk (2010) yang melakukan penelitian di pasar saham Vietnam menggunakan data harian tahun 2000-2008 menemukan bahwa harga minyak mempunyai pengaruh yang positif terhadap harga saham. Saat terjadi krisis ekonomi harga minyak mentah mempunyai pengaruh positif terhadap harga saham.

Penelitian ini tidak konsisten dengan penelitian yang dilakukan oleh Chittedy, Krishnareddy (2011) di pasar saham India selama periode April 2000- Juni 2011. Chittedy menemukan bahwa perubahan harga minyak tidak memiliki pengaruh terhadap harga saham di India.

Hasil pengujian pengaruh harga emas dunia terhadap IHSG di BEI menunjukkan bahwa harga emas dunia mempengaruhi IHSG di BEI. Hasil pengujian ini konsisten dengan penelitian yang dilakukan oleh Indra Wijaya dkk (2008) yang melakukan penelitian di pasar emas di Indonesia selama tahun 2008, menemukan bahwa harga emas dunia mempunyai pengaruh terhadap harga saham, karena emas merupakan pelindung nilai saham dalam jangka panjang. Selain itu, Gary White ( 2002 ) dalam penelitianya yang dilakukan dipasar emas Australia selama tahun 2002 menemukan hasil serupa bahwa emas merupakan salah satu faktor yang mempengaruhi secara positif pergerakan saham di Australia. Graham Smith juga menemukan hasil yang serupa. Penelitian dilakukan dipasar emas Amerika Serikat selama periode 1999-2001 menunjukkan bahwa harga emas dunia berpengaruh terhadap pergerakan saham di Amerika Serikat.

Hasil pengujian pengaruh nilai tukar IDR/US \$ terhadap IHSG di BEI menunjukkan bahwa nilai tukar IDR/US\$ mempengaruhi IHSG di BEI. Hasil penelitian ini konsisten dengan penelitian yang dilakukan oleh Adam dan Tweneboah (2008) pada pasar saham di Ghana dengan menggunakan periode 1991-2007, dijelaskan bahwa depresiasi yang terjadi pada nilai tukar mata uang asing akan berdampak pada naiknya harga barang yang diimpor. Hal ini disebabkan oleh turunya nilai mata uang domestik ( domestic kurs ) sehingga dibutuhkan lebih banyak mata uang domestik yang dikorbankan untuk memperoleh barang impor yang dihargai oleh mata uang asing. Dengan demikian akan mengurangi arus kas pada perusahaan yang kegiatannya mengimpor, dan otomatis akan membuat harga saham perusahaan tersebut menurun.

Hasil ini juga konsisten dengan penelitian yang dilakukan oleh Ajayi (2006) melakukan penelitian di Thailand, Hongkong, Singapura, Korea Selatan dan Taiwan dari 6 Januari 1997 - 31 Desember 1999 menemukan bahwa nilai tukar mata uang asing ( Dollar 
Amerika ) memberikan pengaruh yang negatif dan signifikan terhadap return saham di Korea Selatan, Singapura dan Thailand.

Jadi, berinvestasi saham di Korea Selatan, Singapura dan Thailand cukup beresiko karena fluktuasi harga saham di negara- negara tersebut bergantung pada pergerakan kurs valuta asing. Hanya di Hongkong harga sahamnya tidak terpengaruh oleh pergerakan valuta asing.

Venus dan Huzaimi (2004) dalam penelitianya juga menemukan adanya hubungan sebab akibat antara nilai tukar mata uang asing dan harga saham. Penelitian yang dilakukan di Thailand dan Malaysia pada saat krisi ekonomi tahun 1997-1998 ini menemukan adanya pengaruh dari nilai tukar mata uang asing terhadap harga saham. Selain itu Aydemir dan Demirhan (2009) yang melakukan penelitian dari periode 20012008 di pasar saham Turki juga menemukan adanya pengaruh yang negatif dari nilai tukar mata uang asing terhadap seluruh indeks saham yang ada dipasar saham Turki.

Harga minyak mentah dunia, harga emas dunia dan nilai tukar IDR/US\$ menurut hasil penelitian ini ternyata mempengaruhi IHSG di BEI. Kontribusi pengaruh dari ketiga variabel tersebut adalah sebesar $81,8 \%$ kepada IHSG di BEI. Selain harga minyak mentah dunia, harga emas dunia, dan nilai tukar IDR/US\$, IHSG di BEI juga dipengaruhi sebesar $18,2 \%$ oleh inflasi, suku bunga, money supply, indeks bursa dunia dan faktor ekonomi, sosial dan politik.

Jadi, walaupun menurut gambar (Gambar 1, 2 dan 3) IHSG di BEI tidak terpengaruh oleh guncangan harga minyak mentah dunia dan harga emas dunia yang diakibatkan oleh krisis di kawasan timur tengah tahun 2011.

Namun hasil penelitian menyimpulkan bahwa saat krisis ekonomi dan politik global, harga minyak dunia, harga emas dunia terbukti memberikan pengaruh positif terhadap IHSG di BEI. Krisis ekonomi global ditambah lagi krisis politik di Timur Tengah menyebabkan harga bahan bakar dan perekonomian di Amerika dan Negara berkembang lainnya mengalami penurunan. Hal ini mendorong para investor di Amerika dan Negara berkembang lainnya menarik investasi nya dinegara berkembang dan menanamkan dananya pada Negara emerging market.

Sedangkan nilai tukar IDR/US\$ memberikan pengaruh negatif kepada IHSG di BEI. Tentunya dari hasil penelitian ini kita dapat membuktikan bahwa saat krisis ekonomi dan politik global, harga minyak mentah dunia, harga emas dunia dan nilai tukar IDR/US\$ semuanya mempengaruhi IHSG di BEI. Saat harga minyak mentah dunia dan harga emas dunia mengalami kenaikkan, maka saham IHSG di BEI akan ikut naik. Fenomena menurunya IHSG di BEI disaat minyak mentah dunia dan emas dunia mengalami kenaikan pada periode 8-10 Febuari 2011, mungkin saja hanya bersifat sesaat saja dan bisa juga dipengaruhi oleh faktor-faktor lain seperti inflasi, tingkat suku bunga, money supply, indeks bursa dunia dan faktor ekonomi, sosial dan politik.

Ini dapat menjadi prediktor yang tepat bagi para investor yang ingin berinvestasi di sektor saham khususnya saham IHSG di BEI. Ketika harga minyak mentah dunia naik, maka para investor bisa melakukan investasi di sektor saham karena secara otomatis harga saham khusunya di IHSG juga pasti mengalami kenaikkan, begitupun sebaliknya saat saham di IHSG menurun karena efek menurunya harga minyak mentah dunia, maka investor cendrung tidak berani berinvestasi saham atau akan menahan saham yang investor miliki sambil menunggu harga sahamnya bisa naik kembali.

Seperti halnya minyak, harga emas dunia juga memberikan pengaruh kepada IHSG di BEI. Saat harga emas dunia mengalami kenaikkan, maka secara otomatis harga saham 
IHSG di BEI akan ikut naik. Ini juga dapat dijadikan prediktor yang bagus selain dari harga minyak untuk memprediksi fluktuasi harga saham IHSG di BEI. Selain harga minyak mentah dan emas dunia, nilai tukar IDR/US\$ juga berpengaruh terhadap harga saham IHSG di BEI.

Namun, pengaruh yang diberikan oleh nilai tukar IDR/US\$ berbeda dengan pengaruh yang diberikan oleh minyak dan emas terhadap harga saham IHSG di BEI. Nilai tukar IDR/US\$ memberikan pengaruh yang negatif terhadap saham IHSG di BEI. Ketika Dollar Amerika mengalami kenaikkan, harga saham IHSG di BEI justru akan mengalami penurunan. Ini juga dapat di jadikan sebagai tolak ukur bagi para investor yang ingin melakukan investasi di sektor saham. Jadi, saat yang paling tepat untuk berinvestasi saham menurut hasil penelitian ini adalah ketika harga minyak mentah dan harga emas dunia naik, kemudian harga Dollar Amerika mengalami penurunan.

\section{PNUTUP}

Simpulan. Pertama. Saat Krisis Ekonomi dan Politik global harga minyak mentah dunia positif mempengaruhi IHSG di BEI. Kedua. Saat Krisis Ekonomi dan Politik global harga emas dunia positif mempengaruhi IHSG di BEI. Ketiga. Saat Krisis Ekonomi dan Politik global nilai tukar IDR/US\$ negatif mempengaruhi IHSG di BEI. Keempat. Secara simultan, Saat Krisis Ekonomi dan Politik global harga minyak dunia, harga emas dunia, dan nilai tukar IDR/US\$ mempengaruhi IHSG di BEI.

Saran. Pertama. Sebagai bahan pertimbangan para calon investor dalam melakukan investasi pada saat krisis ekonomi dan politik global, ternyata harga minyak dunia, harga emas dunia dan nilai tukar IDR/US\$ signifikan mempengaruhi IHSG di BEI. Namun mengingat sulitnya memberikan batasan kapan krisis ini mulai terjadi dan kapan berakhir nya serta kesulitan dalam menentukan fluktuasi krisis nya tersebut, maka factor-faktor tersebut menjadi keterbatasan penelitian ini. Keterbatasan penelitian ini juga terdapat pada terbatas nya variabel yang diteliti. Bahwa perubahan IHSG ditentukan oleh banyak faktor atau variabel yang tidak termasuk dalam penelitian ini, sehingga mungkin perubahan IHSG di BEI saat penelitian ini dilakukan sebagai andil dari pergerakan variabel-variabel tersebut yang serupa dengan pergerakan harga minyak mentah, harga emas dunia, dan kurs Rp/USD. Kedua. Penelitian selanjutnya disarankan agar melibatkan variabel-variabel lainnya yang turut mempengaruhi IHSG di BEI guna dapat membedakan variabel mana yang member pengaruh lebih besar terhadap IHSG di BEI sehingga dapat menemukan penemuan-penemuan baru.

\section{DAFTAR RUJUKAN}

Abdalla, I. S. A. and Murinde, V. (1997) Exchange rate and stock price interactions in emerging financial markets: evidence on India, Korea, Pakistan and the Philippines, Applied Financial Economics, 7(1), 25-35

Adam, Anokye M. dan Tweneboah, George. (2008) Do Macroeconomic Variabels Play any Role in the Stock Market Movement in Ghana?. MRPA Paper. no. 9301

Adjasi, C.K.D. and Biekpe, N.B. (2006) "Interest Rate and Stock Market Returns in Africa" African Finance Journal, 8(2), p. 12-27. 
Ajayi, R. A., and Mougoue, M., (1996) "On the Dynamic Relation Between Stock Prices and Exchange Rates.” Journal of Financial Research, 19, 2, 193-207.

Aritonang, Lerbin R. (1998) penelitian pemasaran. Jakarta: UPT Penerbitan Universitas Tarumanagara. ( 2002) Peramalan Bisnis. Jakarta : Ghalia Indonesia.

( 2007 ) Riset Pemasaran Teori dan Praktik. Ghalia Indonesia, Jakarta

Aydemir Oguzhan dan Demirhan, erdal. (2009) The Relationship Between Stock Prices and Exchange Rates Evidence from Turkey. Euro Journals. ISSN 1450-2887 issue 23. hal. 207-215.

Baker Malcolm, Jeremy C. Stein, and Jeffrey Wurgler. (2003) "When Does the Market Matter? Stock Prices and the Investment of Equity-Dependent Firms," Quarterly Journal of Economics, 118, pp. 969-1005.

Bambang Darmadi et.al (2010) Analisis Hubungan Kenaikkan Harga Minyak dan Nilai Kurs Dollar US Terhadap Indeks Harga Saham Gabungan (IHSG) di BEI. UG Jurnal vol 3, no 4, Tahun 2009.

Basher, Syed A. dan Padorsky, Perry. (2004) Oil Price Risk and Emerging Stock Markets. Global Finance Journal, el sevier. vol 17. (2). hal 224-251.

Basu Swastha dan Irawan. (2005) Manajemen Pemasaran Modern. Liberty, Yogyakarta.

Bernheim, B. Douglas, "A Theory of Conformity" Journal of Political Economy v102, n5 (October 1994): 841-77.

Chang, Young ho \& Wong Joo Fong, (2003) “Fluktuasi Harga Minyak dan Perekonomian Singapura," Kebijakan energy, Elsevier, vol. 31 (11), Halaman 1151-1165, September.

Chen, M., Kim, W.G. and Kim, H.J. (2005) "The Impact of Macroeconomic and Nonmacroeconomic Forces on Hotel Stock Returns" Hospitality Management, 24, p. 243-258.

Chittedi, Krishna Reddy (2011) "Integration of International Stock Markets: With Special Reference to India” „GITAM Journal of Management, Vol 9, No 3.

Cong, Rong-Gang \& Wei, Yi-Ming \& Jiao, Jian-Lin \& Fan, Ying, (2008) "Hubungan Antara guncangan Harga Minyak dan Pasar Saham : Analisis Empiris dari China," Kebijakan Energi, Elsevier, vol. 36 (9), halaman 3544-3553, September.

Daryono, Soebagyo, (2003) Analisis faktor-faktor yang mempengaruhi IHSG, Jurnal Ekonomi Pembangunan. vol. 4 no. 2.

Enders, W. (1995) Applied Econometrics Time Series. Iowa University. New York : John Wiley and Sons Inc.

Fama, E.F. (1981) "Stock returns, Real Activity, Inflation and money" American Economic Review, 71(4), p. 545-565.

(1990): "Stock returns, Real Activity, Oil Invesment" American Economic Review, 71(4), p. $84-95$.

Firth, M. (1979) "The Relationship Between Stock Market Returns and Rates of Inflation" Journal of Finance, 34(3), p. 743-749.

Gonzalo, J. and J. Olmo (2005) Contagion Versus Flight to Quality in Financial Markets. University Carlos III Madrid.05-18.

Gultekin, N.B. (1983) "Stock Market Returns and Inflation: Evidence from Other Countries" Journal of Finance, 38(1), p. 49-65.

Hicks, Brian dan Nelder, Chris (2008) Profit From Peak : The End Of Oil and Greatest Invesment Event Of the Century. California : John Wiley and Sons, Inc. 
Huang, R. D., Masulis, R.W. and Stoll, H.R. (1996) Energy shocks and financial markets, Journal of Futures Markets, 16, 1-27.

Huzaimi Hussain \& Venus Khim-Sen Liew, (2004) "Hubungan Kausal Antara Nilai Tukar dan Harga Saham di Malaysia dn Thailand Selama Kekacauan Krisis Mata Uang 1997," International Finance 0405015, EconWPA.

Indra Wijaya dkk. (2008) “ Pengaruh imbal hasil pasar saham dan beberapa indicator makro ekonomi tertentu terhadap imbal hasil saham perusahaan sector barang konsumsi. suatu penelitian empiris di bursa efek Jakarta." Jurnal Ekonomi. Tahun. 13 no. 1 hal. $12-26$.

Jones, Charles Parker. (2002) investment: Analysis and Management. 8th Edition. Carifornia : John Wiley and Sons, Inc.

Kaul, A. and S. Sapp (2007) "Y2k Fears and Safe Haven Trading of the U.S. Dollar." Journal of International Money and Finance In Press, Corrected Proof.

Keown, Arthur J. et.al. (2002) Financial Management Principles and Application : International Edition. $9^{\text {th }}$ Edition. New Jersey: Prentice Hall Inc.

Maysami, R.C. and Koh, T.S. (2000) "A Vector Error Correction Model for the Singapore Stock Market" International Review of Economics and Finance, 9, p. 79-96.

Miskhin, Frederic S. and Eakins, Stanley G. (2000) Financial Market and Institution. $3^{\text {rd }}$ Edition. Boston : Addision Wesley (Ongman).

Morris, Kenneth M.; Siegel, Alan M.; and Morris, Virginia B. (1995) The Wall Street Journal Guide to Planning Your Financial Future. New York: Lightbulb Press.

Mukherjee, T.K. and Naka, A. (1995) "Dynamic Relations Between Macroeconomic Variables and the Japanese Stock Market: An Application of a Vector Error Correction Model" Journal of Financial Research, XVIII (2), p. 223-237.

Osei, K.A. (2006): "Macroeconomic Factors and the Ghana Stock Market" African Finance Journal, 8(1), p. 26-37.

Pahl, Nadine dan Ritcher, anne. (2009) oil price developments - Drivers, Economic Consequences and Policiy Responses. German : GRIN Verlag.

Papapetrou, E. (2001. Oil price shocks, stock markets, economic activity and employment in Greece, Energy Economics, 23, 511-532.

Pindyck, R. and Rotemberg, J. (1990). The excess co-movement of commodity prices. Economic Journal, 100, 1173-1189.

Poterba, James M.; Samwick, Andrew, (1999) "Taxation and Household Portfolio Composition: U.S. Evidence from the 1980s and 1990s," NBER Working Paper: 7392 October.

Rahman, A.R., Sidek, N.R.M. and Tafri, F.H. (2009) "Macroeconomic Determinants of Malaysian Stock Market” African Journal of Business Management, 3(3), p. 95-106.

Sari, R., Hammoudeh, S., and Soytas, U. (2010) Dynamics of oil price, precious metal prices, and exchange rate. Energy Economics, 32, 351-362.

Spyrou, S. (2001) "Stock Returns and Inflation: Evidence from an Emerging Market" Applied Economic Letters, 8(7), p. 447-450.

Soytas, U., Sari R., Hammoudeh, S., and Hacihasanoglu E. (2009) World Oil Prices, Precious Metal Prices and Macroeconomy in Turkey. Energy Policy, 37, 5557-5566.

Sunariyah, (2006) Pengantar Pengetahuan Pasar Modal, Edisi Kelima, UPP STIM YKPN, Yogyakarta.

Thian Hin. (2008) Panduan Berinvestasi Saham Edisi Terkini. Jakarta: PT. Media Elex Komputindo. 